ISSN : 1412-7601

Volume 3, No.1 Maret 2017

http://www.ekonobis.unram.ac.id

EKONOBIS

\title{
Pengaruh Pembiayaan Mudharabah, Pembiayaan Murabahah Dan Ijarah Terhadap Laba Perbankan Syariah Indonesia (Bank Syariah Mandiri)
}

\author{
Nurawwalunnisa \\ Universitas Mataram
}

\begin{tabular}{|c|c|}
\hline ARTICLE INFO & Received : 10 Des 2016; Accepted: 1 Februari 2017; Published: Maret 2017 \\
\hline $\begin{array}{l}\text { Keywords: } \\
\text { Mudharabah Financing, } \\
\text { Murabahah Financing, } \\
\text { ljarah, Net Profit. }\end{array}$ & $\begin{array}{l}\text { ABSTRACT : The research aims to know the influence of mudharabah financing, } \\
\text { murabahah financing and ijarah towards Islamic banking profits. Analytical tools used in } \\
\text { this studi i.e., using multiple regression analysis with independent variabel mudharabah } \\
\text { financing (X1), murabaha financing (X2) and ijarah (X3) as well the dependent variable } \\
\text { i.e., Islamic banking profits (Y). The data on this research data for the financial } \\
\text { statements the Bank Mandiri Syariah in period 2004-2014. } \\
\text { The results showed that partially, mudharabah financing dan murabaha financing is } \\
\text { variable positive significant effect against the Islamic banking profits of Bank Syariah } \\
\text { Mandiri, ijarah while having a negative influence significantly to Islamic banking profit of } \\
\text { Bank Syariah Mandiri. Simultaneously indicate that variable mudharabah financing, } \\
\text { murabaha financing and ijarah simultaneous a positive effect against Islamic banking of } \\
\text { Bank Syariah Mandiri. }\end{array}$ \\
\hline $\begin{array}{l}\text { Kata kunci: } \\
\text { Pembiayaan Mudharabah, } \\
\text { Pembiayaan Murabahah, } \\
\text { Ijarah, Laba Bersih. }\end{array}$ & $\begin{array}{l}\text { ABSTRAK : Penelitian ini bertujuan untuk mengetahui pengaruh antara pembiayaan } \\
\text { mudharabah, pembiayaan murabahah dan ijarah terhadap laba perbankan syariah. Alat } \\
\text { analisis yang digunakan pada penelitian ini yaitu menggunakan analisis regresi beganda } \\
\text { dengan variabel independen pembiayaan mudharabah (X1), pembiayaan murabahah } \\
\text { (X2) dan ljarah (X3) serta variabel dependen yaitu laba bersih (Y). Data pada penelitian } \\
\text { ini merupakan data Laporan Keuangan Bank Mandiri Syariah pada periode 2004-2014 } \\
\text { yang dipublikasikan. } \\
\text { Hasil penelitian menunjukkan bahwa secara parsial, variabel pembiayaan mudharabah } \\
\text { dan pembiayaan murabahah berpengaruh positif signifikan terhadap laba bersih Bank } \\
\text { Syariah Mandiri sedangkan ijarah memiliki pengaruh negatif signifikan terhadap laba } \\
\text { bersih Bank Syariah Mandiri. Secara simultan menunjukkan bahwa variabel pembiayaan } \\
\text { mudharabah, pembiayaan murabahah dan ijarah secara bersama-sama (simultan) } \\
\text { berpengaruh positif terhadap laba bersih Bank Syariah Mandiri.. }\end{array}$ \\
\hline
\end{tabular}

Corresponding Author :

Alamat : Program Studi Ekonomi Pembangunan, Fakultas Ekonomi dan Bisnis, Universitas Mataram, Jln. Majapahit No.

62 Mataram.

e-mail: Nurawwalunnisa@gmail.com 


\section{PENDAHULUAN}

Keadaan perekonomian Indonesia yang memburuk akibat penurunan nilai tukar rupiah menyebabkan masyarakat mulai mencari penghasilan melalui kegiatan bisnis untuk memenuhi kebutuhan hidupnya. Kegiatan bisnis yang dijalankan oleh masyarakat membutuhkan modal dana yang cukup sehingga masyarakat bekerjasama dengan pihak bank. Bank merupakan lembaga intermediasi antara bank dan masyarakat dimana bank menghimpun dana dari masyarakat dan disalurkan kepada masyarakat untuk kegiatan yang meningkatkan taraf hidup. Bank syariah lahir karena adanya keinginginan umat muslim untuk khaffah atau menjalankan aktifitas perbankan sesuai dengan syariah yang diyakini, terutama masalah larangan riba, serta halhal yang berkaitan dengan norma ekonomi dalam Islam seperti larangan maysir (judi dan spekulatif), gharar (unsur ketidakpastian) dan keharusan memperhatikan kehalalan cara dan objek investasi.

Konsep perbankan syariah pada dasarnya bertujuan untuk meningkatkan kesejahteraan umat melalui produkproduk yang berlandaskan syariat Islam yang menurut beberapa pengamat mengalami perkembangan yang cukup pesat, namun pada kenyataannya masih belum dapat menarik minat umat Islam Indonesia untuk menggunakan lembaga perbankan syariah sebagai bagian dari kegiatan perekonomian mereka. Produk pembiayaan pada perbankan syariah di Indonesia telah disesuaikan dengan prinsip-prinsip syariah Islam. Berdasarkan data yang diterbitkan oleh Otoritas Jasa Keuangan, jenis pembiayaan yang tersedia dan berkembang di industri perbankan syariah di Indonesia adalah pembiayaan dengan prinsip bagi hasil (mudharabah dan musyarakah), pembiayaan berdasarkan prinsip jual beli (murabahah dan istishna), pembiayaan berdasarkan prinsip sewa (ijarah) dan pembiayaan qardh. Pembiayaan merupakan fungsi yang penting, maka protofolio pembiayaan pada bank kormersial menempati porsi terbesar, yaitu sekitar 55\%-60\% dari total aktivanya (Arifin,2005).

Produk pembiayaan pada bank syariah menggunakan beberapa konsep akad muamalah antara lain sebagaimana yang akan dibahan pada penelitian ini yaitu mudharabah (kerjasama modal usaha dengan pemilik bank sebagai pemilik modal penuh), murabahah (jual-beli) dan ijarah (kerjasama sewa atau beli suatu barang/jasa). Melalui pendapatanpendapatan tersebut, maka bank dapat mengetahui seberapa besar laba yang dihasilkan pada bank tersebut. Semakin tinggi tingkat laba maka profitabilitas dari bank tersebut akan semakin baik.

Mudharabah berasal dari kata dharb, yang berarti memukul atau berjalan. Pengertian memukul atau berjalan ini dimaksudkan sebagai proses seseorang untuk memukulkan kakinya dalam menjalankan usahanya. Mudharabah merupakan bentuk kontrak antara dua pihak dimana satu pihak berperan sebagai pemilik modal dan mempercayakan sejumlah modalnya untuk dikelola oleh pihak kedua, yakni pelaku usaha dengan tujuan mendapatkan uang (Karim,2006). Sedangkan Antonio (2001) menjelaskan mudharabah sebagai akad kerjasama usaha antara kedua pihak dimana pihak pertama (shahibul maal) menyediakan seluruh modal (100\%) modal, sedangkan pihak lainnya (mudharib) berlaku sebagai pengelola modal.

Murabahah adalah transaksi jual beli suatu barang sebesar harga perolehan barang ditambah dengan margin yang disepakati oleh para pihak, dimana penjual menginformasikan terlebih dahulu harga perolehan kepada pembeli (Peraturan Bank Indonesia No. 9/19/PBI/2007 tentang Pelaksanaan Prinsip Syariah dalam Bank Syariah). ljarah merupakan akad pemindahan hak guna atas barang atau jasa, melalui pembiayaan upah sewa, tanpa diikuti dengan

pemibdahankepemilikan(ownership/milkiy ah) atas barang itu sendiri.

Profit adalah selisih yang timbul ketika total pendapatan suatu perusahaan lebih besar daripada total biaya. Pendapatan 
bagi hasil (profit sharing) ini berlaku untuk produk-produk penyertaan menyeluruh maupun sebagian, atau bentuk bisnis koorporasi (kerjasama). Keuntungan yang dibagihasilkan harus dibagi secara berkaitan dengan bisnis mudharabah, bukan untuk kepentingan pribadi mudharib tetapi juga dapat dimasukkan ke dalam biaya operasional. Keuntungan bersih harus dibagi antara shahibul maal dan mudharib sesuai dengan promosi yang disepakati sebelumnya dan secara ekspesit disebutkan dalam perjanjian awal. Tidak ada pembagian laba sampai semua kerugian telah ditutup dan ekuitas shahibul maal telah dibayar kembali, jika ada pembagian keuntungan sebelum habis masa perjanjian akan dianggap sebagai pembagian keuntungan dimuka (Muhammad, 2005). Salah sati dari tujuan dalam perbankan syariah yaitu memperoleh laba yang merupakan cerminan dari pertumbuhan harta. Islam sangat mendorong pendayagunaan harta/modal dan melarang menyimpannya. Sebagaimana Allah SWT telah menerangkan dalam Al-Qur'an surat Al-Baqarah ayat 188 sebagai berikut : Artinya : Dan janganlah sebahagian kamu memakan harta sebahagian yang lain di antara kamu dengan jalan yang bathil dan (janganlah) kamu membawa (urusan) harta itu kepada hakim, supaya kamu dapat memakan sebahagian daripada harta benda orang lain itu dengan (jalan berbuat) dosa, padahal kamu mengetahui.

Konsep laba dalam Islam sangat diperlukan untuk menentukan besarnya zakat yang harus dibayarkan. Dengan tidak adanya sistem bunga ini tidak berarti bahwa dalam Islam tidak ada biaya dari modal (Achsien,2000). Islam melarang sistem penentuan tingkat pengembalian tetap atas modal. Oleh karena itu, kaitannya dengan konsep laba, laba dijadikan dasar dalam melaksanakan transaksi secara Islam, misalnya laba atau estimasi dari laba (keuntungan dijadikan dasar dalam beberapa produk pembiayaan syariah). Berdasarkan uraian tersebut, maka perlu untuk dilakukan penelitian terhadap produk pembiayaan mudharabah, murabahah dan ijarah yang akan berdampak pada perolehan laba. Tujuan penelitian ini yaitu untuk mengetahui pengaruh antara pembiayaan mudharabah, murabahah dan ijarah terhadap laba perbankan syariah. Berdasarkan tujuan penelitian, maka judul penelitian ini adalah "Pengaruh Pembiayaan Mudharabah, Pembiayaan Murabahah dan ljarah Terhadap Laba Perbankan Syariah".

\section{METODE PENELITIAN}

\section{Jenis Penelitian}

Jenis penelitian ini yaitu penelitian deskriptif kuantitatif. Penelitian deskriptif kuantitatif menjelaskan kedudukan variabel-variabel yang diteliti serta hubungan antara satu variabel dengan variabel lainnya (Sugiyono, 2003). Pada penelitian ini terdapat 4 variabel yang terdiri dari pembiayaan mudharabah (X1), pembiayaan murabahah (X2) dan ijarah (X3) sebagai variabel bebas (independent) serta laba bersih bank syariah $(\mathrm{Y})$ sebagai variabel terikat.

\section{Teknik Pengumpulan Data}

Teknik pengumpulan data pada penelitian ini menggunakan metode dokumentasi dengan mengakses laporan keuangan perusahaan yang di terbitkan oleh Bank Syariah Mandiri (BSM) periode tahun 2004-2014, Bank Indonesia (BI) dan Otoritas Jasa Keuangan (OJK). Jenis data yang digunakan pada penelitian ini yaitu data sekunder yang diperoleh dari laporan keuangan perusahaan.

\section{Definisi Operasional Variabel}

Dalam penelitian ini variabel-variabel penelitian memiliki definisi operasional sebagai berikut :

a. Pembiayaan Mudharabah merupakan akad kerjasama usaha antara dua pihak atau lebih (shahibul maal) dimana pemilik modal memberikan seluruhnya modalnya kepada pengelola (mudharib) dengan sejumlah keuntungan dibagi berdasarkan kesepakatan di awal akad. Indikator perhitungan yang digunakan pada variabel pembiayaan mudharabah (X1) adalah pembiayaan mudharabah. 
b. Pembiayaan Murabahah adalah transaksi jual beli dimana bank menyebut jumlah keuntungannya. Bank bertindak sebagai penjual, sementara nasabah bertindak sebagai pembeli. Harga jual adalah harga beli bank dari pemasok ditambah keuntungan (margin). Indikator perhitungan yang digunakan pada variabel pembiayaan murabahah (X3) adalah pembiayaan murabahah.

c. ljarah merupakan akad pemindahan hak guna atas barang atau jasa, melalui pembayaran upah sewa tanpa diikuti dengan pemindahan kepemilikan atas barang tersebut. Indikator pada variabel ijarah (X3) yaitu pendapatan ijarah.

d. Laba bersih (Y) merupakan jumlah uang yang diterima sebagai suatu proses perubahan oleh perbankan syariah selama periode tahun 20042014 dari total pendapatan dikurangi dengan total biaya atau keuntungan bersih setelah pajak.

Berdasarkan definisi operasional variabel diatas maka dapat digambarkan skema kerangka konseptual pada penelitian ini sebagai berikut :

Gambar 1. Kerangka Konseptual

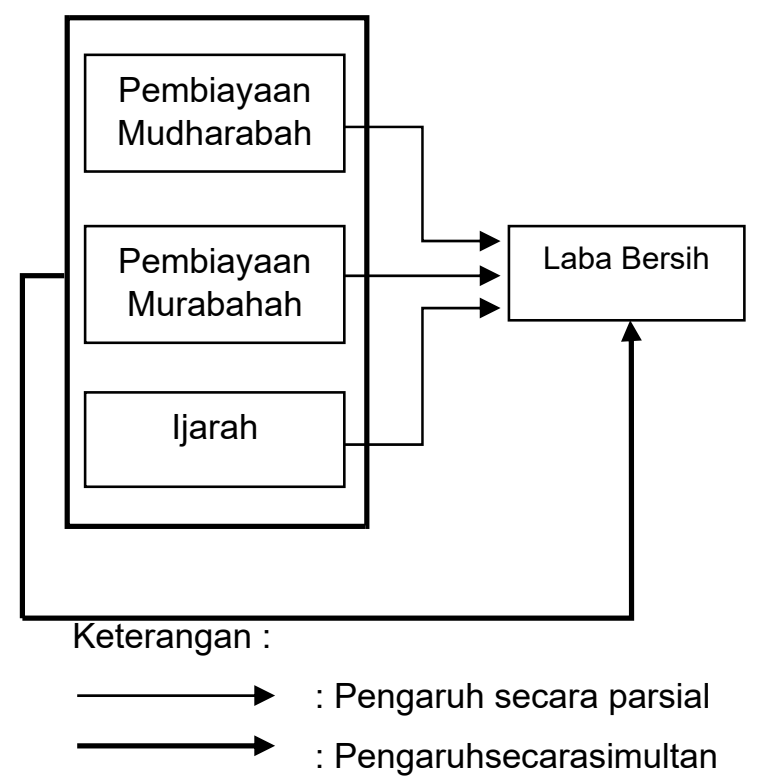

\section{Teknik Analisis Data}

Teknis analisis data pada penelitian ini menggunakan analisis regresi linier berganda. Analisis regresi linier berganda digunakan untuk mengetahui pengaruh beberapa variabel independen satu dengan variabel dependen. Persamaan regresi untuk dua atau lebih variabel adalah sebagai berikut :

$$
Y=a+b_{1} X_{1}+b_{2} X_{2}+b_{3} X_{3}+e
$$

Alat analisis untuk menguji signifikansi pengaruh antar variabel digunakan uji $t$ dan uji F dengan Level Of Significance ( $\alpha$ ) sebesar $5 \%$. Hipotesis yang akan diujikan pada uji t dan uji $\mathrm{F}$ adalah sebagai berikut - Uji t

Ho : Pembiayaan mudharabah, murabahah dan ijarah tidak berpengaruh signifikan secara parsial terhadap laba bersih perbankan syariah.

$\mathrm{H} 1$ : Pembiayaan mudharabah, murabahah, dan ijarah berpengaruh signifikan secara parsial terhadap laba bersih perbankan syariah.

- Uji F

Ho : Pembiayaan mudharabah, murabahah, dan ijarah tidak berpengaruh signifikan secara simultan terhadap laba bersih perbankan syariah.

H1 : Pembiayaan mudharabah, murabahah, dan ijarah berpengaruh signifikan secara simultan terhadap laba bersih perbankan syariah.

Agar hasil analisis dengan menggunakan analisis regresi linier berganda tidak terjadi bias, maka perlu dilakukan uji asumsi klasik terlebih dahulu. Terdapat empat uji asumsi klasik yang harus dipenuhi yakni uji normalitas, uji autokorelasi, uji multikolinieritas, dan uji heterodekastiditas.

\section{HASIL DAN PEMBAHASAN}

Bank Syariah Mandiri (BSM) merupakan salah satu bank syariah terbesar di Indonesia. Sebagai lembaga intermediasi keuangan, Bank Syariah Mandiri melakukan dua aktivitas utama dalam operasionalnya yaitu aktivitas penghimpun dana dari nasabah dan penyaluran dana (pembiayaan) kepada nasabah. Data rasio FDR menjelaskan seberapa besar dana yang dihimpun oleh Bank Mandiri Syariah yang digunakan dalam aktivitas 
pembiayaan bank syariah. Tingkat FDR (Financing to Deposits Ratio) Bank Syariah Mandiri cenderung mengalami peningkatan setiap tahunnya. Hal ini diikuti dengan meningkatnya jumlah pembiayaan yang diberikan oleh Bank Syariah Mandiri yang meningkat hingga $200 \%$.

Peningkatan pembiayaan Mudharabah, Murabahah dan ljarah Bank Syariah Mandiri diikuti dengan peningkatan dari pendapatan pada pembiayaan mudharabah, murabahah dan ijarah. Gambar 3 menerangkan pembiayaan Mudharabah, Murabahah dan ljarah pada Bank Syariah Mandiri periode 2004-2014. Pada gambar tersebut terlihat bahwa peningkatan pembiayaan murabahah mengalami peningkatan setiap tahunnya jika dibandingkan dengan pembiayaan mudharabah dan ijarah.

\section{Pengujian Asumsi Klasik}

Uji asumsi klasik dilakukan untuk mengetahui apakah penggunaan model regresi berganda dalam menganalisis telah memenuhi asumsi klasik atau tidak. Pengujian asumsi klasik dilakukan dengan 4 asumsi klasik yaitu uji normalitas, uji autokorelasi, uji heterokedastisitas, dan uji multikolonieritas.

Berdasarkan hasil uji normalitas data terlihat bahwa variabel pembiayaan mudharabah, pembiayaan murabahah dan ijarah serta laba bersih memiliki sebaran data berdistribusi normal. Hal ini dijelaskan pada gambar 4 dimana grafik menunjukkan adanya penyebaran data disekitar garis diagonal dan mengikuti arah garis diagonal, sehingga bisa dikatakan bahwa model regresi yang dihasilkan telah memenuhi asumsi normalitas.

\section{Gambar 2. Grafik Hasil Uji Normalitas}

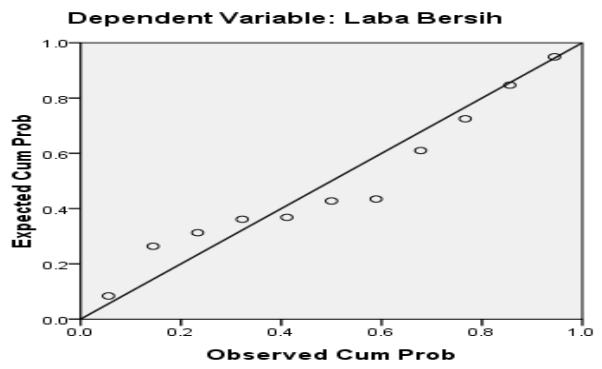

Sumber : Data Diolah (Lampiran 2)
Hasil uji autokorelasi ditunjukkan dengan nilai Durbin-Watson sebesar 2.234. suatu data dikatakan terbebas dari gangguan autokorelasi apabila nilai D-W terletad antara $d u<d<4-d u$. Uji heterokedastisitas ditunjukkan oleh pola pada scatterplot. Pada grafik terlihat titik-titik tidak membentuk suati pola tertentu dan menyebar secara acak serta tersebar baik diatas maupun dibawah angka 0 pada sumbu Y, maka dapat disimpulkan bahwa tidak terjadi heterokedastisitas pada model regresi yang digunakan.

Gambar 3. Grafik Hasil Uji Heterokedastisitas

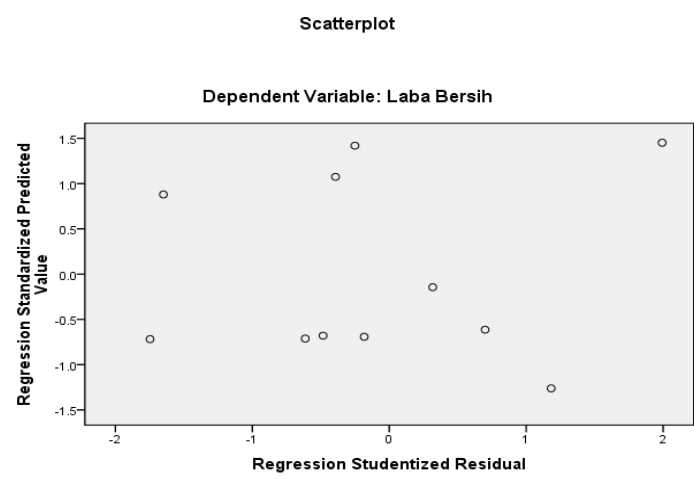

Sumber : Data Diolah (Lampiran 2).

Uji multikolonieritas dilihat pada nilai VIF dan nilai tolerance. Jika nilai VIF lebih kecil dari 10 dan nilai tolerance lebih dari 0,1 , maka dapat disimpulkan bahwa data tidak mengalami gangguan multikolonieritas. Berdasarkan tabel 1 dapat disimpulkan bahwa model regresi yang digunakan tidak terjadi multikolonieritas.

Tabel 1. Hasil Uji Multikolonieritas

\begin{tabular}{|c|c|c|}
\hline \multirow{2}{*}{ Variabel } & \multicolumn{2}{|c|}{ Collinearity Statistic } \\
\cline { 2 - 3 } & Tolerance & VIF \\
\hline $\begin{array}{c}\text { Pembiayaan } \\
\text { Mudharabah (X1) }\end{array}$ & 0.542 & 1.843 \\
\hline $\begin{array}{c}\text { Pembiayaan } \\
\text { Murabahah (X2) }\end{array}$ & 0.383 & 2.612 \\
\hline ljarah (X3) & 0.631 & 1.584 \\
\hline
\end{tabular}

Sumber : Data Diolah (Lampiran 3). 
Hasil Analisis Regresi Berganda

Hubungan metode pendugaan parameter pada analisis regresi berganda menggunakan bantuan program SPSS versi 16. Hasil persamaan regresi yang didapatkan dari pengaruh variabel penjelas terhadap laba bersih periode tahun 2004-2014 sebagai berikut :

$Y=72.726+0.079 X 1+0.016 \times 2-0.896 X 3$

Tabel 2. Hasil Regresi

\begin{tabular}{|l|c|c|c|c|}
\hline \multirow{2}{*}{ Variabel } & \multicolumn{2}{|c|}{$\begin{array}{c}\text { Unstandardized } \\
\text { Coeficients }\end{array}$} & $\begin{array}{c}\mathrm{t}- \\
\text { statistic }\end{array}$ & \multirow{2}{*}{ Sig. } \\
\cline { 2 - 4 } & $\mathrm{B}$ & Std.errors & & \\
\hline Constant & 72.726 & 56.076 & 1.297 & 0.236 \\
\hline $\begin{array}{l}\text { Mudharabah } \\
(\mathrm{X} 1)\end{array}$ & 0.079 & 0.022 & 3.571 & 0.009 \\
\hline $\begin{array}{l}\text { Murabahah } \\
(\mathrm{X} 2)\end{array}$ & 0.016 & 0.003 & 4.629 & 0.002 \\
\hline ljarah (X3) & -0.896 & 0.151 & -5.941 & 0.001 \\
\hline $\begin{array}{l}\mathrm{R}=0.967 \\
R^{2}=0.935 \\
t_{\text {tab }}=2.2009 \\
\mathrm{~F}=33.704 \\
F_{\text {tab }}=3.59 \\
\text { Sig }=0.000\end{array}$ & & & \\
\hline
\end{tabular}

Sumber: Data Diolah (Lampiran 3).

Berdasarkan hasil regresi didapatkan hasil bahwa pembiayaan mudharabah memiliki pengaruh yang positif terhadap laba bersih. Nilai koefisien variabel mudharabah sebesar 0.079 yang artinya ketika pembiayaan mudharabah mengalami peningkatan sebesar 1 satuan maka akan meningkatkan pendapatan laba bersih sebesar 0.079. Nilai t-statistik lebih besar dari nilai $t$ tabel yang artinya variabel pembiyaan mudharabah memiliki pengaruh yang signifikan terhadap laba bersih.

Perubahan yang terjadi pada pendapatan mudharabah memiliki pengaruh terhadap tingkat laba bersih. Peningkatan pendatapan yang terjadi pada pembiayaan mudharabah akan meningkatkan laba bersih suatu perbankan. Kualitas investasi pada mudharabah dapat didasarkan atas tingkat kesesuaian antara realitas bagi hasil dengan preyeksinya, kondisi keuangan dan prospek usaha (Muhammad,2005).
Pembiayaan mudharabah dan murabahah memiliki pengaruh terhadap laba bersih Bank Syariah Mandiri. Pelaksanaan pembiayaan yang meliputi realisasi mudharabah, dan murabahah secara umum memiliki hubungan terhadap kinerja profitabilitas bank umum hanya ditentukan oleh realisasi pembiayaan namun profitabilitas diperoleh melalui pos-pos income yang lain. Misalkan melalui administrasi tabungan, administrasi ATM dan transaksi antar bank (Fadhila,2015).

Biaya yang dikeluarkan dalam pengelolaan pembiayaan mudharabah juga memberikan kontribusi untuk laba bank syariah. Namun pendapatan yang diberikan masih rendah jika dibandingkan dengan pembiayaan dengan akad jual beli. Oleh karenanya sumbangan pendapatan dari akad bagi hasil belum mampu mengoptimalkan kemampuan bank umum syariah dalam menghasilkan laba. Bank syariah masih belum mampu mengelola pembiayaan bagi hasilnya dengan baik agar mendapat laba yang optimal dikarenakan risiko pembiayaan mudharabah lebih besar dibandingkan pembiayaan jual beli, akibatnya pembiayaan mudharabah kurang diminati oleh para nasabah.

Pembiayaan murabahah memiliki pengaruh positif terhadap laba bersih Bank Syariah Mandiri, dilithat dari nilai koefesien sebesar 0.016 artinya ketika pembiayaan murabahah meningkat sebesar 1 satuan akan meningkatkan laba bersih sebesar 0.016. Nilai t-statistik sebesar 4.629 lebih besar dari nilai t-tabel sehingga vaeriabel pembiayaan murabahah berpengaruh positif signifikan terhadap laba bersih. Pembiayaan murabahah memiliki pengaruh yang dominan terhadap laba bersih Bank Syariah Mandiri.

Pembiayaan murabahah memang lebih diminati oleh para nasabah dibandingkan dengan pembiayaan mudharabah dan ijarah. Pembiayaan murabahah dianggap memiliki risiko yang lebih kecil karena pembiayaan murabahah merupakan investasi jangka pendek yang cukup mudah dengan pendapatan mark-up yang bisa ditentukan sehingga mengurangi risiko. Pembiayaan jual beli merupakan pola pembiayaan terbesar yang selama ini 
disalurkan bank umum syariah yang didomonasi oleh pembiayaan murabahah. Murabahah merupakan metode palinh dominan dalam menginvestasikan dana dalam perbankan Islam dan untuk tujuantujuan praktis, dengan risiko yang kecil dan memberikan keuntungan yang ditetapkan dimuka kepada bank atas modalnya.

Risiko yang rendah pada pembiayaan murabahah memungkinkan bank untuk lebih mudah mengelola pembiayaan dengan prinsip jual beli baik melalui akad merabahah. Pengelolaan yang mudah membuat bank semakin menyukai pembiayaan murabahah dan menjadikannya sebagai kekuatan bank dalam hal pembiayaan. Maka pembiayaan murabahah dianggap sebagai asset bank syariah untuk meningkatkan pendapatan bank itu sendiri.

Variabel pembiayaan ijarah memiliki tanda negatif yang berarti jika pendapatan ijarah semakin besar maka akan menurunkan besarnya tingkat laba bersih. Menurut Muhammad dalam Emha (2014) pada saat bank mengeksekusi kredit macetnya, bank tidak memperoleh hasil yang memadai, karena jaminan yang tidak sebanding dengan besarnya kredit yang diberikan. Resiko kredit muncul manakala bank tidak mampu memperoleh kembali tagihannya atas pinjaman yang diberikan. Pembiayaan yang bermasalah (macet) akan membuat bank mempunyai kewajiban untuk melakukan Penyisihan Pencadangan Aktiva Produtif (PPAP) sebesar $100 \%$ dari modal yang belum dikembalikan, sehingga laba akan menurun. Hal ini disebabkan oleh adanya potensi risiko yang harus ditanggung oleh modal bank sendiri yang mengandung konsekuensi atas aktiva yang dibentuk dengan PPAP.

\section{KESIMPULAN DAN SARAN}

Berdasarkan hasil penelitian maka dapat disimpulkan bahwa :

1. Bedasarkan hasil uji hepotesis menggunakan uji $\mathrm{t}$ menunjukkan bahwa variabel pembiyaaan mudbarabah dan muarabahah berpengaruh postif signifikan terhadap laba bersih bank syariah secara parsial sedangkan ijarah memiliki pengaruh negatif terhadap laba bersih.

2. Pembiayaan murabahah memiliki pengaruh yang paling dominan terhadap laba bersih Bank Syariah Mandiri. Hal ini dikarenakan pada akad pembiayaan murabahah risiko yang dimiliki rendah jika dibandingkan dengan pembiayaan lainnya, prosesnya yang cukup mudah juga membuat para nasabah lebih memilih pembiayaan ini.

3. Berdasarkan hasil uji hipotesis menggunakan uji $F$ menunjukkan bahwa variabel pembiayaan mudharabah,pembiayaanmurabaha $h$ dan ijarah secara bersama-sama (simultan) berpengaruh positif terhadap laba bersih Bank Syariah Mandiri.

4. Laba dipengaruhi oleh biaya-biaya yang terjadi diantaranya biaya operasional atas pengawasan dan evaluasi aktivitas nasabah pada seluruh sektor pembiayan mudharabah, laba akan meningkat jikabankmampumenekan/menguran gi biaya tersebut.

5. Bank Syariah Mandiri mampu mempertahankandanmeningkatkan pembiyaan murabahah dengan cara melakukan inovasi pada produk murabahah, sehingga laba yang yang dihasilkan juga akan semakin meningkat. Hal ini didasarkan atas jenis pembiayaan murabahah yang difokuskan pada aktivitas jual beli.

Beberapa saran yang dapat diberikan dalam penelitian antara lain, Bank Syariah Mandiri dapat melakukan efisiensi biaya atas penerapan pembiayaan mudharabah. Hal ini dikarenakan pemanfaatan dana pembiayaan yang rendah perputarannya akibat faktor krisis global, kelangkaan bahan baku, cuaca, musim pancaroba Indonesia. Secara umum perdangangan (jual-beli) di Indonesia memiliki persentase yang cukup tinggi serta memiliki perputaran dana yang sangat efektif.jenis pembiayaan murabahah inilah yang menjadi kekuatan/sumber laba bagi 
bank-bank syariah di Indonesia. Pada dasarnya ada beberapa hal yang mempengaruhi laba Bank Syariah Mandiri, antara lain : kenaikan pendapaan (baik mudharabah,murabahah dan ijarah) yang dipengaruhi oleh minat masyarakat dan keamampuan Bank Syariah Mandiri dalam mensosialisasikan produkproduknya. Namun perlu kajian lebih lanjut untuk meneliti faktor-faktor lainnya yang mempengaruhi laba

\section{DAFTAR PUSTAKA}

Achsien, Iggi Harruman. 2000. Konsep dan Praktik Manajemen Portofolio Syariah pada Rashid Husein Berhad Unit Trust Manajemen (RHBUTM) Malaysia. Jakarta : FE UI.

Al Qur'an dan Terjemahannya. 2004. Departemen Agama RI . Surabaya : Mekar Surabaya.

Antonio, Muhammad Syafi'i. 2001. Bank Syariah Dari Teori Ke Praktik. Jakarta : Gema Insani.

Arifin, Zainul. 2006. Dasar-Dasar Manajemen Bank Syariah. Jakarta : Pustaka Alvabet.

Bank Indonesia. Peraturan Bank Indonesia No. 9/19/PBI/2007 tentang Pelaksanaan Prinsip Syariah dalam Kegiatan Pemhimpunan Dana dan Penyaluran Dana serta Pelayanan Jasa Bagi Bank Syariah. http:www.bi.go.id. diakses tgl 8 Januari 2016 pukul 12.35 WIB.

Emha, Muhammad Busthomi. 2014. Analisis Pengaruh Pembiayaan Mudharabah, Musyarakah dan ljarah Terhadap Kemampu Labaan Bank Muamalat di Indonesia. Jurnah IImiah. Universitas Brawijaya. Malang.

Fadhila, Novi. 2015. Analisis Pembiayaan Mudharabah dan Murabahah Terhadap Laba Bank Syariah Mandiri. Jurnal Riset Akuntansi dan Bisnis. Volume.15. No.1. Maret.

Karim, Adiwarman A. 2006. Bank Islam : Analisis Fiqh dan Keuangan. Jakarta : PT. Rajagrafindo.

Muhammad. 2005. Sistem dan Prosedur Operasional Bank Syariah. Yogyakarta : UII Press.

Permata, Ressely Inti Dwi, dkk. 2014. Analisis Pengaruh Pembiayaan Mudharabah dan Musyarakah Terhadap Tingkat Profitabilitas (Return On Equity) : Studi pada Bank Umum Syariah yang Terdaftar di Bank Indonesia Periode 2009-2012. Jurnal Administrasi Bisnis (JAB). Vol. 12. No.1. Juli.

Reinissa. 2015. Pengaruh Pembiayaan Mudharabah, Musyarakah dan Muarabahah Terhadap Profitabilitas Bank Syariah Mandiri, TBK. Jurnal IImiah. Universitas Brawijaya. Malang.

Sugiyono. 2003. Metode Penelitian Administrasi. Bandung : Alfabeta.

Uyanto, Stanislaus S. 2009. Pedoman Analisis Data dengan SPPS. Yogyakarta : Graha IImu.

Wangsa, Sugianto dan Tan Ming Kuang. 2011. Analisis Pengukuran, Pengklasifikasian dan Pengakuan Pendapatan pada Bank Konvensional dan Bank Syariah. Jurnal IImiah Akuntansi. Nomor.6. Tahun ke-2. September-Desember.

www.bi.go.id. Diakses tgl. 14/01/2016. Pukul.09.36 WIB.

www.syariahmandiri.co.id/category/investor-relation/diakses tgl 13/01/2016 pukul.17.18 WIB. 